\title{
Effects of the Reduction or Withdrawal of the Vitamin Premix from the Diet on Chicken Performance and Meat Quality
}

\section{Euthor(s)}

Moravej $\mathrm{H}$

Alahyari SM*

Shivazad M

Department of Animal, Faculty School of Agriculture and Natural Resources, The University of Tehran, Karaj, 31587-77871, Iran

\section{-Mail Adress}

Corresponding author Tel: +989351103551; fax: +982612249752;

E-mail: Majid.alahyari@ut.ac.ir

\section{aKeywords}

Vitamin premix, broiler, floor, performance, wheat, TBARS.

\begin{abstract}
The present study was carried out to examine the effect of vitamin premix reduction or withdrawal in finisher diet (29 to 42 days of age) on the performance and meat quality of chicks fed a wheat/barley based diet and reared on floor pens. A total of 504 male broiler chicks (Ross ${ }^{\circledR}$ 308) were allocated to seven treatment groups, with four replicates per treatment and 18 birds per replicate. All data were analyzed according to a completely randomized design. Results showed that the reduction or withdrawal of the vitamin premix from diets in different weeks of finisher period did not affect chicken performance $(p>0.05)$. There were no significant differences in TBARS values of thigh samples of birds slaughtered at 35 days of age. However, the TBARS value of the treatment without vitamin premix was significantly higher than in the other treatments $(p<0.05)$ when birds were slaughtered at 42 days of age. Finally, the results of this study demonstrated that it is not possible withdrawal all premix vitamin of the diet. However, it may be possible to reduce vitamin supplements in finisher broiler diets without any negative effects on performance or meat quality during freezing.
\end{abstract}

\section{INTRODUCTION}

The removal of vitamin supplements from broiler finisher diets has received considerable attention during the past few years. Vitamins are organic compounds present in most feedstuffs in minute amounts. However, vitamins are essential for normal metabolism. Also, they can cause specific deficiency diseases if absent from the diet and cannot be synthesized by the host animal to meet vitamin requirements (Coelho \& McNaughton, 1995). Several reports have demonstrated that vitamin premix removal from broiler finisher diets based on corn did not significantly affect broiler performance or humoral immune response (Skinner et al., 1992; Christmas et al., 1995; Maiorka et al., 2002; Khajali et al., 2006). Further studies on the withdrawal or reduction of vitamin supplements in finisher diets are required because:

1. It is not clear that the level of vitamin $\mathrm{E}$ in broilers meat is sufficient to stabilize quality after slaughter and long storage times in the freezer. Lipid oxidation is the main cause of meat quality deterioration, because products of autoxidation of unsaturated fatty acids affect the wholesomeness and nutritional value of the final product (Pearson et al., 1993). Lipid oxidation is an important determinant of shelf life of meats and meat products. Lipids in poultry show higher degree of unsaturation than red meats due to a relatively high content of phospholipids (Igene \& Pearson, 1979). The degree of unsaturation of the phospholipids of the subcellular membrane is an important factor in determining the oxidative stability of meats, with the oxidative potential 
increasing as the degree of unsaturation of meat lipids increases. Phospholipids are located in membrane structures, and the initiation of lipid peroxidation in tissues has been tracked to the membrane level (Machlin, 1984). Vitamin $E$ is part of the body's intracellular defense against the adverse effects of reactive oxygen species and free radicals that initiate oxidation of unsaturated phospholipids (Chow, 1979).

2. There is a lack of reports on the removal vitamin premix from broiler finisher diets based on wheat and barley. The volatility of global corn prices may the use of wheat and barley instead of corn in broiler diets. Also, there are differences between vitamin content in wheat, barley and corn.

Therefore this study was carried out to evaluate the effects of the reduction or withdrawal of vitamin supplements from diets based on wheat and barley during the finisher period on performance and meat quality of broilers.

\section{MATERIAL AND METHODS}

\section{General Proe}

\section{Birds and housing}

Chick average initial body weight was $42 \mathrm{~g}$. Room temperature was kept at $34^{\circ} \mathrm{C}$ during the first three days of the trial and then gradually reduced as bird aged until $22^{\circ} \mathrm{C}$ at 21 days of age. Continuous light was supplied during the first three days, after which the lighting regimen was 23 hours/day. Chicks were raised up to 29 days of age and were fed commercial starter and grower diets that met their nutritinal requirements (Aviagen, 2007). Male broiler chicks (Ross 308) were distributed into pens according to completely randomized design with seven treatments with four replicates of 18 birds per replicate. Birds were reared in floor pens.

\section{Dietary treatments}

Treatments are described in Table 1: T1 - feed with no vitamin premix (VP), from 29 to 42 days of age; T2 $33 \%$ VP, from 29 to 42 days of age; T3 - 33\% VP from 29 to 35 days of age and no VP from 36 to 42 days of age; T4 - 66\% VP, from 29 to 42 days of age; T5 $66 \%$ VP from 29 to 35 days of age and no VP from 36 to 42 days of age; $T 6-100 \% \mathrm{VP}$, from 29 to 42 days of age; T7 - 100\% VP from 29 to 35 days of age and no VP from 36 to 42 days of age.
The ingredient and nutritional composition of the experimental diets are shown in Table 2. Mash feed and water were offered ad libitum.

Table 1 - Composition of diets used during the experimental period ( 29 through $42 \mathrm{~d}$ of age).

\begin{tabular}{lcccc}
\hline Ingredients (\%) & $\begin{array}{c}\text { Treat- } \\
\text { ment1 }\end{array}$ & $\begin{array}{c}\text { Treat- } \\
\text { ment2/3 }\end{array}$ & $\begin{array}{c}\text { Treat- } \\
\text { ment4/5 }\end{array}$ & $\begin{array}{c}\text { Treat- } \\
\text { ment6/7 }\end{array}$ \\
\hline Wheat & 36.38 & 36.05 & 35.97 & 35.79 \\
\hline Barley & 30.00 & 30.00 & 30.00 & 30.00 \\
\hline Soybean meal (44\%) & 27.93 & 28.09 & 28.04 & 28.09 \\
\hline Soybean oil & 2.74 & 2.80 & 2.86 & 2.90 \\
\hline Oyster shell & 1.24 & 1.25 & 1.24 & 1.24 \\
\hline Dicalcium phosphate & 0.89 & 0.90 & 0.90 & 0.90 \\
\hline Vitamin premix & 0.00 & 0.08 & 0.16 & 0.25 \\
\hline Trace mineral premix ${ }^{3}$ & 0.25 & 0.25 & 0.25 & 0.25 \\
\hline Sodium chloride & 0.28 & 0.28 & 0.28 & 0.28 \\
\hline DL-Methionine & 0.17 & 0.18 & 0.17 & 0.17 \\
\hline L-Lysine-HCl & 0.07 & 0.07 & 0.07 & 0.07 \\
\hline Multi Enzyme (Rova- & 0.05 & 0.05 & 0.05 & 0.05 \\
\hline bio ${ }^{4}$ & 100 & 100 & 100 & 100 \\
\hline Total & & & & \\
\hline Calculated composition ${ }^{\#}$ & 2,900 & 2,900 & 2,900 & 2,900 \\
\hline ME (kcal/kg) & 20.00 & 20.00 & 20.00 & 20.00 \\
\hline CP (\%) & 0.37 & 0.37 & 0.37 & 0.37 \\
\hline Met (\%) & 0.73 & 0.73 & 0.73 & 0.73 \\
\hline Met + Cys (\%) & 0.97 & 0.97 & 0.97 & 0.97 \\
\hline Lys (\%) & 0.16 & 0.16 & 0.16 & 0.16 \\
\hline Na (\%) & 0.76 & 0.76 & 0.76 & 0.76 \\
\hline Ca (\%) & 0.37 & 0.37 & 0.37 \\
\hline Available P(\%) & & & & \\
\hline & & & & \\
\hline
\end{tabular}

' $T 1$ - Without VP, during 29 to 42 days of age; T2 - 33\% VP, during 29 to 42 days of age; T3 $-33 \%$ VP during 29 to 35 days of age and without VP during 36 to 42 days of age; T4 - $66 \%$ VP, during 29 to 42 days of age; T5 - 66\% VP during 29 to 35 days of age and without VP during 36 to 42 days of age; T6 - 100\% VP, during 29 to 42 days of age; $T 7-100 \%$ VP during 29 to 35 days of age and without VP during 36 to 42 days of age.

$22.5 \mathrm{~kg}$ of vitamin premix contained: $2700 \mathrm{mg}$ retinal, $400 \mathrm{mg}$ calcidiol, $18 \mathrm{~g}$ tocopheryl acetate, $2000 \mathrm{mg}$ menadione, $1800 \mathrm{mg}$ thiamine, $6600 \mathrm{mg}$ riboflavin, $10 \mathrm{~g}$ niacin, $30 \mathrm{~g}$ calcium pantothenate, $3 \mathrm{~g}$ pyridoxine, $1 \mathrm{~g}$ folic acid, $15 \mathrm{mg}$ cobalamin, $250 \mathrm{~g}$ choline chloride, $100 \mathrm{mg}$ biotin.

$2.5 \mathrm{~kg}$ of trace mineral premix contained: $100 \mathrm{~g} \mathrm{Mn}, 50 \mathrm{~g} \mathrm{Fe}, 100 \mathrm{~g} \mathrm{Zn}, 10 \mathrm{~g} \mathrm{Cu}, 1 \mathrm{~g}$ I, 200mg Se.

${ }^{4}$ This product contained mainly $\beta$-glucanase and xylanase activities. The endo-1,3(4)$\beta$-glucanase $100 \mathrm{AGL} / \mathrm{kg}$ diet and endo-1,4- $\beta$ - xylanase $70 \mathrm{AXC}$ units/ $\mathrm{kg}$ diet. \#Based on a dry matter content of $86 \%$. 
Table 2 - Composition of the starter and grower diets used in the pre-experimental phases.

\begin{tabular}{|c|c|c|}
\hline Ingredients (\%) & Starter diet & Grower diet \\
\hline Wheat & 34.00 & 35.14 \\
\hline Barley & 32.00 & 30.00 \\
\hline Soybean meal (44\%) & 23.97 & 26.93 \\
\hline Corn Gluten meal & 5.62 & 2.51 \\
\hline Soybean oil & 1.03 & 1.80 \\
\hline Oyster shell & 1.30 & 1.29 \\
\hline Dicalcium phosphate & 1.05 & 1.05 \\
\hline Vitamin premix ${ }^{1}$ & 0.25 & 0.25 \\
\hline Trace mineral premix ${ }^{2}$ & 0.25 & 0.25 \\
\hline Sodium chloride & 0.28 & 0.28 \\
\hline DL-Methionine & 0.07 & 0.21 \\
\hline L-Lysine- $\mathrm{HCl}$ & 0.13 & 0.24 \\
\hline $\begin{array}{l}\left.\text { Multi Enzyme (Rovabio }{ }^{\circledast}\right) \\
\text { Total }\end{array}$ & $\begin{array}{l}0.05 \\
100\end{array}$ & $\begin{array}{l}0.05 \\
100\end{array}$ \\
\hline \multicolumn{3}{|l|}{ Calculated composition } \\
\hline ME (kcal/kg) & 2,850 & 2,870 \\
\hline $\mathrm{CP}(\%)$ & 20.80 & 20.00 \\
\hline Met (\%) & 0.48 & 0.41 \\
\hline Met + Cys (\%) & 1.00 & 0.86 \\
\hline Lys (\%) & 1.35 & 1.12 \\
\hline $\mathrm{Na}(\%)$ & 0.15 & 0.14 \\
\hline $\mathrm{Ca}(\%)$ & 0.99 & 0.81 \\
\hline Available Phosphorus (\%) & 0.47 & 0.41 \\
\hline
\end{tabular}

$12.5 \mathrm{~kg}$ of vitamin premix contained: $2700 \mathrm{mg}$ retinal, $400 \mathrm{mg}$ calcidiol, $18 \mathrm{~g}$ tocopheryl acetate, $2000 \mathrm{mg}$ menadione, $1800 \mathrm{mg}$ thiamine, $6600 \mathrm{mg}$ riboflavin, $10 \mathrm{~g}$ niacin, 30g calcium pantothenate, $3 \mathrm{~g}$ pyridoxine, $1 \mathrm{~g}$ folic acid, $15 \mathrm{mg}$ cobalamin, $250 \mathrm{~g}$ choline chloride, $100 \mathrm{mg}$ biotin.

$2.5 \mathrm{~kg}$ of trace mineral premix contained: $100 \mathrm{~g} \mathrm{Mn}, 50 \mathrm{~g} \mathrm{Fe}, 100 \mathrm{~g} \mathrm{Zn}, 10 \mathrm{~g} \mathrm{Cu}, 1 \mathrm{~g}$ I, 200mg Se.

Prior to formulation, all main dietary ingredients were analyzed for AMEn, amino acid (AA) profile (according to prediction formula pulbished in NRC, 1994), crude protein (CP), crude fiber (CF), and ether extract (EE) contents, as described by AOAC (2000).

\section{Productive performance traits}

At 29 days of age, body weights were similar in all pens $(1135 \pm 14 \mathrm{~g})$. Mortality from 29 to 42 days was determined for each pen. Feed intake and body weight were determined at 29, 35 and 42 days of age. Feed conversion ratio was based these data and calculated per period and for the complete experimental period. Feed intake was adjusted for mortality. Birds that died during the experiment were weighed, and their body weight was included in calculations of feed conversion ratio. Feed waste was recorded per replicate for each period.

\section{Thiobarbituric acid (TBARS) value}

Thighs from two birds slaughtered per replicate were stored in individual oxygen-permeable plastic bags at $-20^{\circ} \mathrm{C}$ (frozen storage) until chemical analysis performed after 180 days. Thighs were thawed and ground, and their oxidative stability was measured in TBARS values. The TBARS value (expressed as malonaldehyde equivalents) was colorimetrically determined by the method of Porkony \& Dieffenbacher (1989), as described by Kirk \& Sawyer (1991). A portion (200 mg) of sample was weighed into a $25 \mathrm{~mL}$ volumetric flask. An aliquot (1 mL) of 1-Butanol was added to dissolve the sample. The mixture was made to volume and mixed. A portion $(5 \mathrm{~mL})$ of the mixture was pipetted into a dry stopper test tube and $5 \mathrm{~mL}$ of TBA reagent (prepared by dissolving $200 \mathrm{mg}$ of 2-TBA in $100 \mathrm{~mL} 1$-butanol, filtered, stored at $4^{\circ} \mathrm{C}$ for not more than seven days) were added. The test tubes were closed, vortexed and placed in water bath at $95^{\circ} \mathrm{C}$ for $120 \mathrm{~min}$ and then cooled. Absorbance (As) was measured at $530 \mathrm{~nm}$ against water blank. A reagent blank was run and absorbance (Ab) was recorded. TBA Value (mg of malonaldehyde/kg of tissue) was obtained by the formula:

$$
\text { TBARS }=\frac{(A-B) \times 50}{M} \times 1000
$$

Where:

$A$ is the absorbance of the test solution

$B$ is the absorbance of the reagent blank

$M$ is the mass in $\mathrm{mg}$, of the test portion

50 is a factor valid if the volume of the volumetric flask is $25 \mathrm{ml}$ and cell width $10 \mathrm{~mm}$ (Mihara \& Uchiyama, 1978).

\section{Statistical Analysis}

Data were submitted to analysis of variance (ANOVA) as a completely randomized design using the GLM procedures of SAS software package (SAS, 2002). Means were compared by Duncan's Multiple Rang Test at a significance level of $p<0.05$.

\section{RESULTS}

Mortality for all groups was within the expected range and was not significantly different among treatments. Average daily feed intake (ADFI), body 
Table 3 - Effect of vitamin premix reduction or withdrawal on broiler performance.

\begin{tabular}{|c|c|c|c|c|c|c|c|c|c|c|}
\hline \multirow[b]{2}{*}{ Treatments } & \multicolumn{3}{|c|}{$29-35 d$} & \multicolumn{3}{|c|}{$36-42 d$} & \multicolumn{3}{|c|}{$29-42 d$} & \multirow[b]{2}{*}{$\begin{array}{l}\text { Body weight } \\
42 \text { day (g) }\end{array}$} \\
\hline & $\begin{array}{l}\text { Average daily } \\
\text { feed intake } \\
\text { (g/day) }\end{array}$ & $\begin{array}{l}\text { Body weight } \\
\text { gain (g/day) }\end{array}$ & $\mathrm{FCR}^{1}$ & $\begin{array}{l}\text { Average daily } \\
\text { feed intake } \\
\text { (g/day) }\end{array}$ & $\begin{array}{l}\text { Body weight } \\
\text { gain (g/day) }\end{array}$ & FCR & $\begin{array}{l}\text { Average daily } \\
\text { feed intake } \\
\text { (g/day) }\end{array}$ & $\begin{array}{l}\text { Body weight } \\
\text { gain (g/day) }\end{array}$ & $\mathrm{FCR}$ & \\
\hline T 1 & 145 & 85 & 1.71 & 172 & 91 & 1.88 & 159 & 88 & 1.80 & 2366 \\
\hline T 2 & 143 & 83 & 1.73 & 169 & 89 & 1.91 & 156 & 86 & 1.82 & 2361 \\
\hline T 3 & 145 & 87 & 1.66 & 169 & 86 & 1.95 & 157 & 87 & 1.81 & 2390 \\
\hline T 4 & 146 & 86 & 1.70 & 169 & 96 & 1.80 & 157 & 91 & 1.73 & 2395 \\
\hline T 5 & 147 & 86 & 1.70 & 170 & 94 & 1.81 & 158 & 90 & 1.76 & 2393 \\
\hline T 6 & 145 & 87 & 1.66 & 172 & 94 & 1.84 & 159 & 90 & 1.75 & 2395 \\
\hline T 7 & 146 & 87 & 1.68 & 171 & 93 & 1.85 & 159 & 90 & 1.77 & 2391 \\
\hline SEM & 3.4 & 17.52 & 0.05 & 4.1 & 5.1 & 0.07 & 2.6 & 3.0 & 0.04 & 25.4 \\
\hline
\end{tabular}

${ }^{1}$ Feed conversion ratio (FCR) $(\mathrm{g} / \mathrm{g})$

weight gain (BWG), and feed conversion ratio (FCR) results are shown in Table 3. VP reduction or withdrawal at different ages did not significantly affect ADFI, BWG or FCR $(p>0.05)$.

The TBARS values of thigh samples after six months of storage in a in freezer are presented in Table 4. TBARS values of the thigh samples of birds slaughtered at 35 days of age were not significantly different $(p>0.05)$. However, TBARS values of T1 chicks were significantly higher than relative to the other treatments $(p<0.05)$, when birds were slaughtered at 42 days of age.

Table 4 - Effect of storage time on the oxidative stability (TBARS values - mg malondialdehyde/kg tissue) of thighs from birds were slaughtered at 35 and 42 days of age.

\begin{tabular}{ccc}
\hline & TBA 35d & TBA 42 d \\
\cline { 2 - 3 } & 1.66 & $3.57^{\mathrm{b}}$ \\
\hline T 2 & 1.36 & $2.18^{\mathrm{a}}$ \\
\hline T 3 & 1.53 & $1.83^{\mathrm{a}}$ \\
\hline T 4 & 1.27 & $1.83^{\mathrm{a}}$ \\
\hline T 5 & 1.49 & $1.85^{\mathrm{a}}$ \\
\hline T 6 & 1.37 & $1.81^{\mathrm{a}}$ \\
\hline T 7 & 1.35 & $1.88^{\mathrm{a}}$ \\
\hline SEM & 0.15 & 0.16 \\
\hline
\end{tabular}

${ }^{a-b}$ Values in the same column within each experiment with different superscripts differ significantly $(p<0.05)$.

\section{DISCUSSION}

\section{Performance}

Although vitamins do not supply energy, they act as cofactors in several metabolic reactions, thus increasing the efficiency of synthesis pathways in the animal. Because broilers have high vitamin requirements during rearing, it would be expected that reducing dietary vitamin levels during the finisher period would increase feed conversion.

The findings of the present study were consistent with those reported by Skinner et al. (1992) and Khajali et al. (2006), who showed that vitamin and mineral premix withdrawal from broiler finisher diets did not affect their performance. Skinner et al. (1992) suggested that the lack of a withdrawal effect could be related to the availability of vitamins and minerals in the body for further growth, as the amount of these supplements usually exceeds two or three times the recommended broiler requirements.

On the other hand, omitting vitamins from the finisher diet for the same period decreased weight gain in three different broiler strains (Deyhim \& Teeter, 1993; Patel et al., 1997). Deyhim \& Teeter (1993) also demonstrated that broilers reared in battery cages, under cycling ambient temperature (24 to $35^{\circ} \mathrm{C}$, creating heat stress), and fed diets without vitamin and mineral supplement presented reduced weight gain, increased mortality and compromised feed conversion when compared with birds fed normally supplemented diets. These differences may be due to the type of rearing system (floor or cages) or differences in diet composition. 


\section{Lipid Oxidation in Thigh Meat}

Vitamin E functions as a quenching agent of freeradical molecules presenting single, highly reactive electrons. Highly reactive oxygen species, such as superoxide anion radical $\left(\mathrm{O}_{2}\right)$, hydroxyl radical $(\mathrm{HO})$, hydrogen peroxide $\left(\mathrm{H}_{2} \mathrm{O}_{2}\right)$, and singlet oxygen $\left(\mathrm{O}_{2}\right)$, are continuously produced in the course of normal aerobic cellular metabolism. Also, phagocytic granulocytes undergo respiratory burst to produce oxygen radicals to destroy intracellular pathogens. However, these oxidative products can, in turn, damage healthy cells if they are not eliminated. Antioxidants serve to stabilize these highly reactive free radicals, thereby maintaining the structural and functional integrity of cells (Chew, 1995; McDowell, 2000). Therefore, antioxidants are very important to animal health. Vitamin E oxidation prevents the oxidation of lipids and consequent formation of free radicals and peroxides within cells, protecting the cell membrane from damage (Drouchner, 1976). If lipid hydroperoxides are allowed to form in the absence of adequate tocopherols, direct cellular tissue damage can result, in which peroxidation of lipids destroys structural integrity of the cell and causes metabolic disorders. Vitamin $\mathrm{E}$ reacts or functions as a chain-breaking antioxidant, thereby neutralizing free radicals and preventing oxidation of lipids within membranes. Free radicals may not only damage their cell of origin, but migrate and damage adjacent cells in which more free radicals are produced in a chain reaction leading to tissue destruction (Nockels et al., 1996). Bartov \& Frigg (1992) showed that oxidative stability was best in tissues from broilers that received vitamin E continuously during the trial and presumably had higher alpha-tocopherol contents in the meat. However, it seems that withdrawal of vitamin premix did not have significantly effects on broiler performance, but it can damage tissues by decreasing the vitamin $\mathrm{E}$ requirements for stable quality meat during freezing.

\section{CONCLUSIONS}

The results of the present study demonstrated that it is not possible to apply full vitamin premix withdrawal in finisher broiler diets; its levels may be reduced with no negative effects on performance or meat quality during freezing.

\section{REFERENCES}

AOAC. Official methods of analysis. 17th ed. Arlington: Association of Agricultural Chemists; 2000.
Aviagen. Ross broiler (308) management manual. Newbridge; 2007

Bartov I, Frigg M. Effect of high concentrations of dietary vitamin E during various age periods on performance, plasma vitamin $E$ and meat stability of broiler chicks at 7 weeks of age. British Poultry Science 1992; 33:393-402.

Chew BP. Antioxidant vitamins affect food animal immunity and health. Journal of Nutrition 1995; 6:1804-1808.

Chow CK. Effect of dietary selenium and vitamin E on the antioxiant defense systems of rat erythrocytes. International Journal Vitamin and Nutrition Research 1979; 2:182-195.

Christmas R, Harms R, Sloan D. The absence of vitamins and trace minerals and broiler performance. Journal of Applied Poultry Research 1995; 4:407-410

Coelho MB, McNaughton JL. Effect of composite vitamin supplementation on broilers. Journal of Applied Poultry Research 1995; 4:219-229.

Deyhim F, Teeter RG. Dietary vitamin and/or trace mineral premix effects on performance, humoral mediated immunity and carcass composition of broilers during thermoneutral and high ambient temperature distress. Journal of Applied Poultry Research 1993; 2:347-355.

Drouchner W. Current status of vitamin E research presented on the example of the vitamin E requirements and supply status of the pig. Basel: Hoffmann-La Roche; 1976; p.93.

Khajali F, Asadi Khoshoei E, Zamani M. Effect of vitamin and trace mineral withdrawal from finisher diets on growth performance and immunocompetence of broiler chickens. British Poultry Science 2006; 47:159-162

Kirk RS, Sawyer R. Pearson's composition and analysis of foods. 9th ed. Essex: Longman Scientific and Technical England; 1991. p.607-617.

Igene JO, Pearson AM. Role of phospholipids and triglycerides in warmedover flavor development in meat model systems. Journal of Food Science 1979; 44:1285-1290.

Machlin LJ. Handbook of vitamins: nutritional, biochemical and clinical aspects. New York: Marcel Dekker; 1984. pp.90.

Maiorka A, Laurentiz AC, Santin E, Araujo LF, Macari M. Dietary vitamin or mineral mix removal during the finisher period on broiler chicken performance. Journal of Applied Poultry Research 2002; 11:121-126.

McDowell LR. Vitamins in animal nutrition. In: McDowell LR, editor. Comparative Aspects to Human Nutrition. Introduction and historical considerations. London: Academic Press; 2000. p.150-198.

Mihara M, Uchiyama M. Determination of malonaldehyde precursor in tissues by thiobarbituric acid test. Analytical Chemistry 1978; 1:271278.

Nockels CF, Odde KG, Craig AM. Vitamin E supplementation and stress affect tissue alpha-tocopherol content of beef heifers. Journal of Animal Science 1996; 3:672-687

NRC (National Research Council). Nutrient requirement of poultry. 9th ed. Washington (DC): National Academic Press; 1994.

Patel KP, Edwards HM, Baker DH . Removal of vitamin and trace mineral supplements from broiler finisher diets. Journal of Applied Poultry Research 1997; 6:191-198.

Pearson AM, Gray Jl, Wolzak AM, Horenstein NA. Safety implications of oxidized lipids in foods. Journal of Food Technology 1983; 37:121129. 
Pokorny J, Dieffenbacher A. Determination of 2-thiobarbituric acid value: Direct method. Results of a collaborative study and the standardised method. Journal of Pure and Applied Chemistry 1989; 61:1165-1170.

SAS Institute. SAS User's guide, statistics. Cary; 2002.

Skinner JT, Waldroup AL, Waldroup PW. Effects of removal of vitamin and trace mineral supplements from grower and finisher diets on live performance and carcass composition of broilers. Journal of Applied Poultry Research 1992; 1:280-286. 